\title{
Evaluation of the Upper Paraná River discharge controlled by reservoirs
}

\author{
Souza Filho, EE. \\ Departamento de Geografia-GEMA-PEA, Universidade Estadual de Maringá - UEM, \\ Av. Colombo, 5790, CEP 87020-900, Maringá, PR, Brazil \\ *e-mail: edvardmarilia@wnet.com.br \\ Received December 5, 2008 - Accepted March 3, 2009 - Distributed June 30, 2009
}

(With 9 figures)

\begin{abstract}
The building of large dams in the Upper Paraná River basin altered the discharge regime at the Porto São José River section. The discharge regime has been altered since 1972, but the changes intensified after the Porto Primavera damming, in late 1998. Considering that discharge control affects the relationship between channel and floodplain, this work aimed to evaluate the intensity of the discharge control that resulted from the operation of the Porto Primavera Dam. To achieve this objective, statistical analyses were carried out based on the Porto São José Fluviometric Station historical series of river level readings and discharge, between 1964 and 2007 . Results showed that the average discharge increased from 1964 to 1981 and diminished after river damming. The increase of average discharge rates was followed by an increase of the duration of higher discharges at different levels of geomorphologic and limnological importance, and the reduction of average discharge during the last observed period was followed by a disproportionate decrease in the duration of the abovementioned discharges. Moreover, it is clear that the relationship between fluviometric level and fluvial discharge changed, which implies that a certain river level reading represents a higher discharge than necessary before river damming.
\end{abstract}

Keywords: fluvial discharge, controlled fluvial regime, dam control, Paraná River.

\section{Avaliação do controle de descarga do Alto Rio Paraná por reservatórios}

\section{Resumo}

A construção de grandes barragens na bacia do Alto Rio Paraná alterou o regime de descargas na seção fluvial de Porto São José. O regime de descargas começou a ser alterado a partir de 1972, e o controle tornou-se mais intenso após formação do reservatório de Porto Primavera, no final de 1998. Uma vez que o controle de descargas afeta as relações entre o canal e a planície, o objetivo deste trabalho foi avaliar a intensidade do controle das descargas efetuado pela barragem de Porto Primavera. Para isso foram realizadas análises estatísticas das séries históricas de cotas fluviométricas e de descarga fluvial da Estação Fluviométrica de Porto São José (PR) para o período entre 1964 e 2007. Os resultados obtidos permitiram verificar que houve um aumento da descarga média de 1964 a 1988 e uma diminuição após o fechamento da barragem. O aumento da descarga média foi acompanhado por um aumento do tempo de permanência em descargas superiores aos diversos níveis com importância geomorfológica e limnológica, e a diminuição da descarga média no último período foi acompanhada por uma redução desproporcional do tempo de permanência das descargas mencionadas. Alem disso, foi verificado que a relação cota-vazão foi alterada e assim, uma determinada cota fluviométrica representa uma descarga mais elevada que a necessária durante o período anterior à barragem.

Palavras-chave: descarga fluvial, regime controlado, controle de barragens, Rio Paraná.

\section{Introduction}

The historical series of the Porto São José River Fluviometric Station shows that the Paraná River discharge regime changed after the operation of other dams upstream from this area. Discharge regime changes occurred as other reservoirs were built, regulating the Paraná River fluviometric level (Rocha et al., 1998; 2001; Rocha, 2002). The construction of Porto Primavera Dam, completed in November 1998, intensified such control (Silva, 2007).
Geomorphologic changes occur because of river discharge regulation. The relationship between channels and the fluvial plain also changes, either by magnitude, duration (number of days above a given reading level), periodicity, frequency, water flow rate (Rocha, 2002), sediment transport (Souza Filho, 1999; Rocha, 2002; Crispin, 2001; Martins and Stevaux, 2005; Hayakawa, 2007), or by river channel alterations (Souza Filho, op. cit.; Souza Filho et al., 2004). Under such circumstances, flood ex- 
tent, plain flood duration and sediment transport change. Geomorphologic modifications alter the processes and structure in both channel and plain, and consequently, connectivity between river and the plain is also altered (Corradini, 2006; Ibarra, 2008).

Assuming that the disturbing source is the discharge regime, this paper aimed to evaluate the intensity of the outflow controlled by the Porto Primavera Dam, based on the Porto São José Station fluviometric data. It also aimed to discuss some consequences on the river dynamics of the Paraná River segment downstream from this dam.

\subsection{Study area}

The study area is located on the border of the following Brazilian states: Mato Grosso do Sul, São Paulo and Paraná. It includes the Paraná River channel and the floodplain from the Porto Primavera Dam (Engenheiro Sergio Motta) to Ivinheima River (Figure 1).

The Porto São José Fluviometric Station is located at Porto São José City, in the Paraná State riverside, approximately $35 \mathrm{~km}$ downstream from the Porto
Primavera Dam and a few kilometers downstream from the Paranapanema River mouth. The station register is 64575003 (ANA - Water National Agency). Its historical series started on October $1^{\text {st }}, 1963$. There is another station approximately $90 \mathrm{~km}$ downstream, named Porto Caiuá, whose register number is 64618500 . It is located upstream from the Ivaí River mouth. Its historical series started on June $8^{\text {th }}, 1989$. There is only one important affluent between both stations, the Ivinheima River.

The Paraná River has multiple channels separated by large river islands (Figure 1), and it can be characterized as a multichannel river system. The riverbed was mostly formed by large bed forms (sand macro-waves, subaqueous macro-dunes, sand waves and subaqueous dunes) and large cross-channel bars (Souza Filho and Stevaux, 1997a; 1997b; 2004). Today, most of the bed forms have disappeared or diminished, except the large river bars (Souza Filho et al., 2004).

The river-floodplain system is wide and lies on the right bank (state of Mato Grosso do Sul), although is-
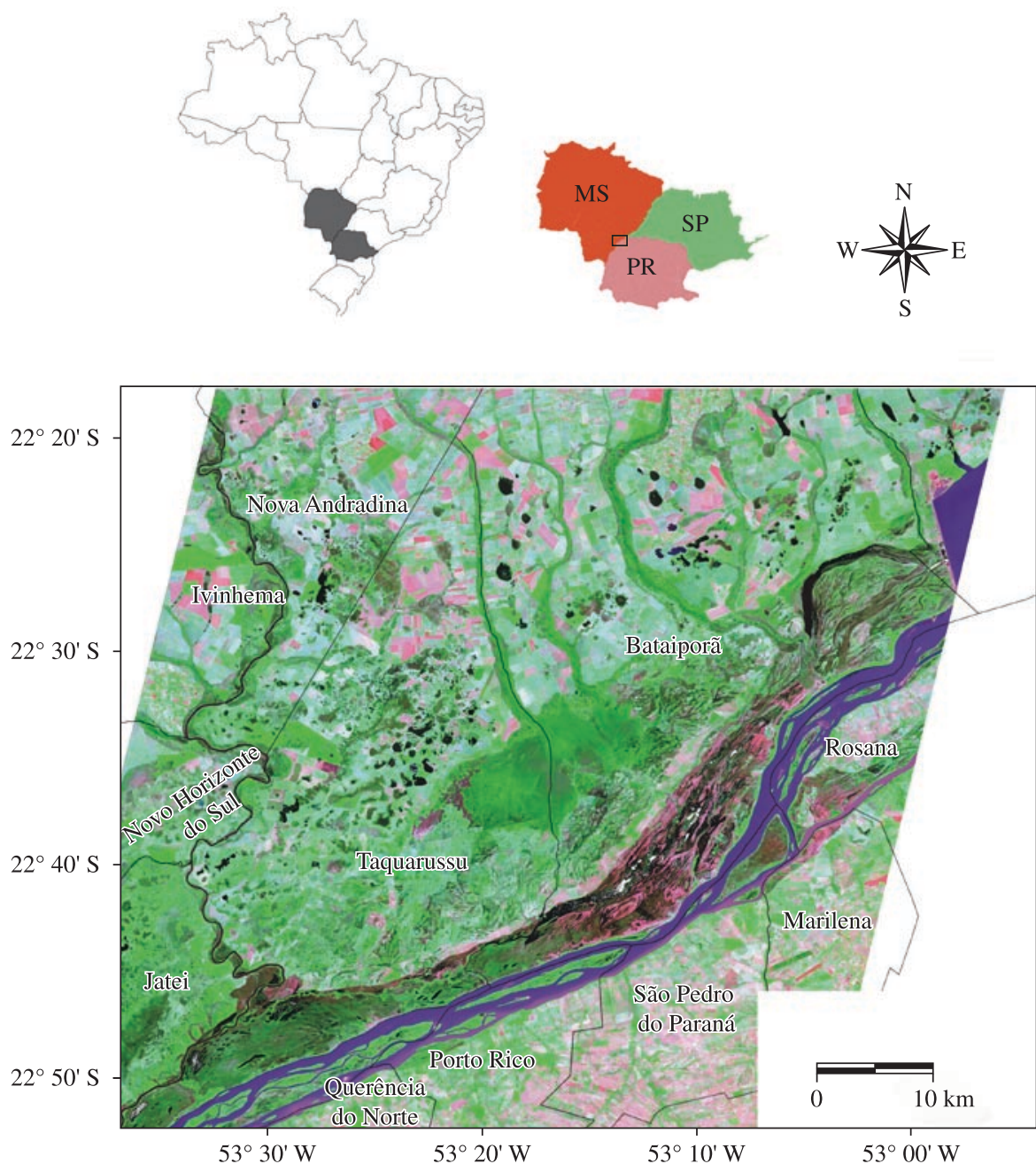

Figure 1. Study area location (modified from Andrade, 2008). 
lands also represent a significant portion of the plain (Figure 1). The plain is cut by active river channels (Baia River, Curutuba River channel and Ivinheima River) and by sub-active channels where water flows only during flooding periods. In addition to these forms, there is a considerable set of lakes, streams and areas subject to flooding (flooding basin), intermediate areas (deposits of crevasse splay), and higher areas (paleobars, natural levees) (Figure 2). Such features represent different subenvironments of an anastomosed system, which was active until 1,500 years ago. (Souza Filho, 1994) and was partially modified by the current forms.

Different altitudes are determined on the floodplain by the distinct geomorphologic features, although they are only a few meters high. On one hand, a rise of the Paraná River water level may waterlog or flood large areas. On the other hand, a water level decrease may dry up large areas of the plain. Similarly, the water level variation may connect or disconnect lentic water bodies with the river system.

Plain water inflow may occur due to the floods of the Paraná River, Ivinheima River or the Baía River (in case of local downpours). Paraná River floods, Ivinheima River floods, or floods from both rivers initially affect the plain at the point where the Curutuba channel and the Ivinheima River meet, and then they flood the entire plain (Comunello et al., 2003). There are no river data to characterize the Baía river dynamics.

During floods, Parana River water flows into the plain and groundwater rises until lentic bodies connect to each other. When this occurs, the Porto São José Station reads $3.5 \mathrm{~m}$ (discharge of $9,900 \mathrm{~m}^{3} / \mathrm{s}$ ) according to Rocha (2002) and Thomaz et al. (2004). When the river level reaches $4.6 \mathrm{~m}\left(12,745 \mathrm{~m}^{3} / \mathrm{s}\right)$, the Curutuba/ Ivinheima areas flood due to water inflows by the lowlying banks of river channels and lakes. The intermediate parts of the plain start flooding at $6.0 \mathrm{~m}\left(16,356 \mathrm{~m}^{3} / \mathrm{s}\right)$, and the higher lands are flooded at $7.0 \mathrm{~m}\left(19,335 \mathrm{~m}^{3} / \mathrm{s}\right)$. These data were obtained from Rocha (2002), confirmed by Meurer (2004) and by Corradini (2006), all showing little difference on river levels.

During the Ivinheima River floods, the onset of the water inflow by groundwater has not been determined yet, but the plain starts flooding at $2.5 \mathrm{~m}\left(472 \mathrm{~m}^{3} / \mathrm{s}\right)$ at the Ivinheima River Station. General flooding starts at $4.0 \mathrm{~m}(890 \mathrm{~m} / \mathrm{s})$, according to Rocha (2002) and Meurer (2004).

The plain is affected in a distinct way according to the three above mentioned river dynamics. Rocha (2002) defined the influence areas of each river's course, and

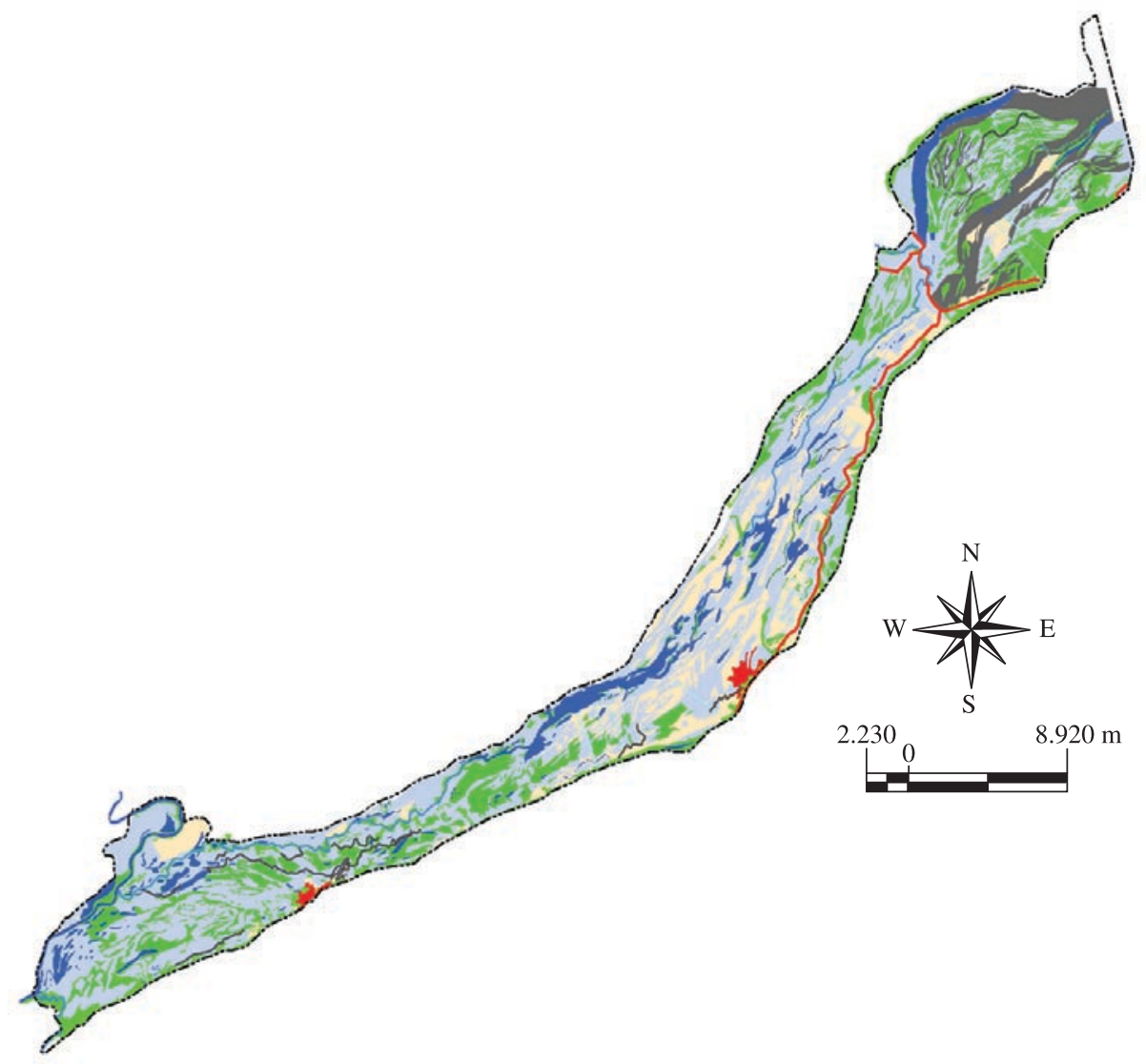

Figure 2. Geomorphologic features of the Paraná River floodplain, showing the water (blue), natural levee (green), swamp (light blue). (Modified from Andrade, 2008). 
called them the Ivinheima, Paraná and Baía Inundation Zones (Figure 3). The area concerning the Paraná Inundation Zone is affected by the dam, including the whole Baía Flooding Zone and the lower area of the Ivinheima Flooding Zone.

\section{Material and Methods}

Available bibliographic data, including river geomorphology, Paraná River discharge dynamics and historical series of the Porto São José and Porto Caiuá Stations' level readings and discharge rates were employed to carry out this work. Literature analysis followed the temporal order of the papers, since each paper approached river data before its completion. River data were taken from ANA (HidroWeb) and updated with data supplied by ITAIPU Binacional.

Data of river level readings were analyzed in order to obtain the annual average level readings from 1964 to 2007. These data were grouped in different time intervals, according to the control level performed by dams (from 1964 to 1971; from 1972 to 1981 ; from 1982 to 1998; and from 1999 to 2007). Time intervals are discussed below. As defined by Rocha (2002), data for river level were organized in order to facilitate the assessment of river discharge for each time interval, as a way of evaluating the geomorphologic action of the waters over the plain and the connection intensity between lentic bodies and river channels.

Finally, Porto São José and Porto Caiuá Station data were compared in order to check the modifications in the relationship between hydrologic level and fluvial dis-

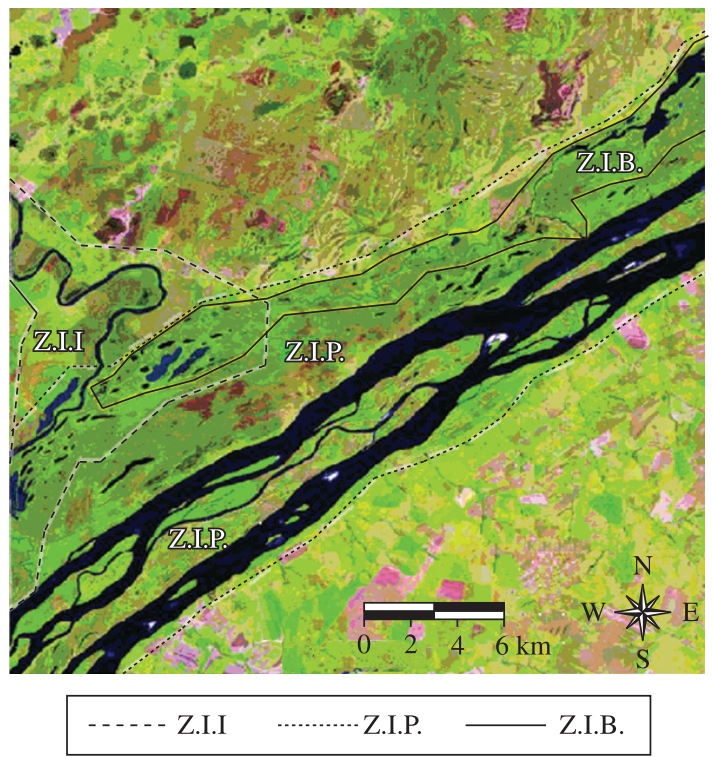

Figure 3. Occurrence area of the Ivinheima (Z.I.I.), Paraná (Z.I.P.) and Baía (Z.I.B) Flooding Zone, according to Rocha (2002). charge. The approach analyzed the correlation (Pearson) between the data for river level and discharge rates of the Porto São José series (from 1964 to 2007) to check alterations that occurred during the research period. The coefficient of determination $\left(\mathrm{R}^{2}\right)$, obtained by fitting a polynomial regression of each time interval between data on fluviometric levels and discharge, was used to evaluate the association between these variables. The same procedure was applied to check the stage-discharge curve used before 1998 .

The comparison between the stations was carried out with data from 1990 to 2006. This time interval was used because data for river level readings from Porto Caiuá Station are limited to this period of time. The $\mathrm{R}^{2}$ of a polynomial regression was also used to evaluate the association between the data for river level readings and the discharge rate of both stations.

\section{Results}

Porto São José Station river level readings showed a systematic modification beginning in 1972; since then, the average values for river levels increased. Before 1972, the annual average of the daily average discharge levels recorded at Porto São José Station was $2.34 \mathrm{~m}$ $\left(6,501 \mathrm{~m}^{3} / \mathrm{s}\right)$, and between 1972 and 1998, it increased to $3.48 \mathrm{~m}\left(9,150 \mathrm{~m}^{3} / \mathrm{s}\right)$ (Rocha et al., 1998). These authors noticed that during the mentioned period, the duration of the lowest discharges was reduced, and that from 1982 to 1993 (the last year analyzed by these authors), the duration of low discharges was even more reduced, whereas the duration of high and average discharges and floods increased considerably.

Later work conducted by Rocha (2002) refined this analysis. He observed the behavior of the magnitude, duration, regularity, frequency and rate of alteration of flows and defined four different time intervals with different control conditions. The time interval before 1972 was called the Natural Regime Period and the time interval after 1972 was called the Modified Regime Period (or Controlled Regime Period). The latter period was subdivided into three other intervals by the author: the Transitional Period (from 1972 to 1981), the Regulated by the Cascade of Dams Effect Period (from 1982 to 1998) and the Regulated by the Porto Primavera Hydroelectric Power Plant Period (from 1999 to 2001, last analyzed year).

The last three periods were analyzed again by Silva (2007), who evaluated the variability and the temporal distribution of river flows between 1976 and 2006. Silva observed that the annual average discharge during the Transitional Period was $9,144 \mathrm{~m}^{3} / \mathrm{s}$ (water level reading: $3.47 \mathrm{~m}), 9,772 \mathrm{~m}^{3} / \mathrm{s}$ during the Regulated by the Cascade Effect Period (water level reading: $3.73 \mathrm{~m}$ ), and $7,816 \mathrm{~m}^{3} / \mathrm{s}$ during the Regulated by the Porto Primavera Hydroelectric Power Plant Period (water level reading: $2.94 \mathrm{~m})$ 
Silva's (2007) average values of minimum and maximum discharges for the three periods showed that during the first period, the water level reading varied between 1.91 and $6.90 \mathrm{~m}$. During the second period, the water level readings varied between 2.10 and $6.34 \mathrm{~m}$, and during the third period, the water level readings varied between 1.90 and $5.24 \mathrm{~m}$. Such data show the gradual control of dams, which significantly reduced the range of water level variation.

\subsection{The annual average river levels and duration of river discharges}

Differences between the abovementioned periods are better observed when the numbers of days on which the water level reached or exceeded the geomorphologic and limnological significant river level readings are compared. Figure 4 shows the number of days on which the river reached or exceeded the 3.5, 4.6, 6.0 and 7.0 m levels, in Porto São José Station, between 1964 and 2007.

During the Natural Period (from 1964 to 1971), the Porto São José Station series reported an average river level of $2.55 \mathrm{~m}(6,952 \mathrm{~m} / \mathrm{s})$, which represents a period of relatively low discharges. Major discharges occurred in
1965 and 1967, whereas annual average minor discharges occurred in 1969 and 1971 (Figure 5a). The discharge duration in different river intervals is shown in Figure 4a. The years 1965 and 1966 must be highlighted because of river levels greater than $7 \mathrm{~m}$, and the year 1969 must be highlighted due to a non-significant discharge.

During the Transitional Period, the average river level was $3.22 \mathrm{~m}\left(8,500 \mathrm{~m}^{3} / \mathrm{s}\right)$, and, because of high annual averages (Figure 5b), the years 1976 and 1980 must be highlighted. The lowest annual average discharge occurred in 1975, even though the annual average level was higher than $2.5 \mathrm{~m}$. The discharge duration in different fluviometrical levels is shown in Figure 4b. In 1974, 1977 , and 1980, the water level rose over $7.0 \mathrm{~m}$ high, whereas in 1972, 1975, and 1979, the water level did not rise higher than $6.0 \mathrm{~m}$, although it had risen over $4.6 \mathrm{~m}$.

During the Regulated by the Cascade of Dams Effect Period, the average level was considerably raised ( $3.62 \mathrm{~m}$, equivalent to $9,550 \mathrm{~m}^{3} / \mathrm{s}$ ), which was due to the high river discharges that occurred in 1982 and 1983; the greatest flood event ever occurred in the Paraná River, considering available data. Moreover, the annual averages of the other years were also high (Figure 5c). The duration in each interval is shown in Figure 4c. The year
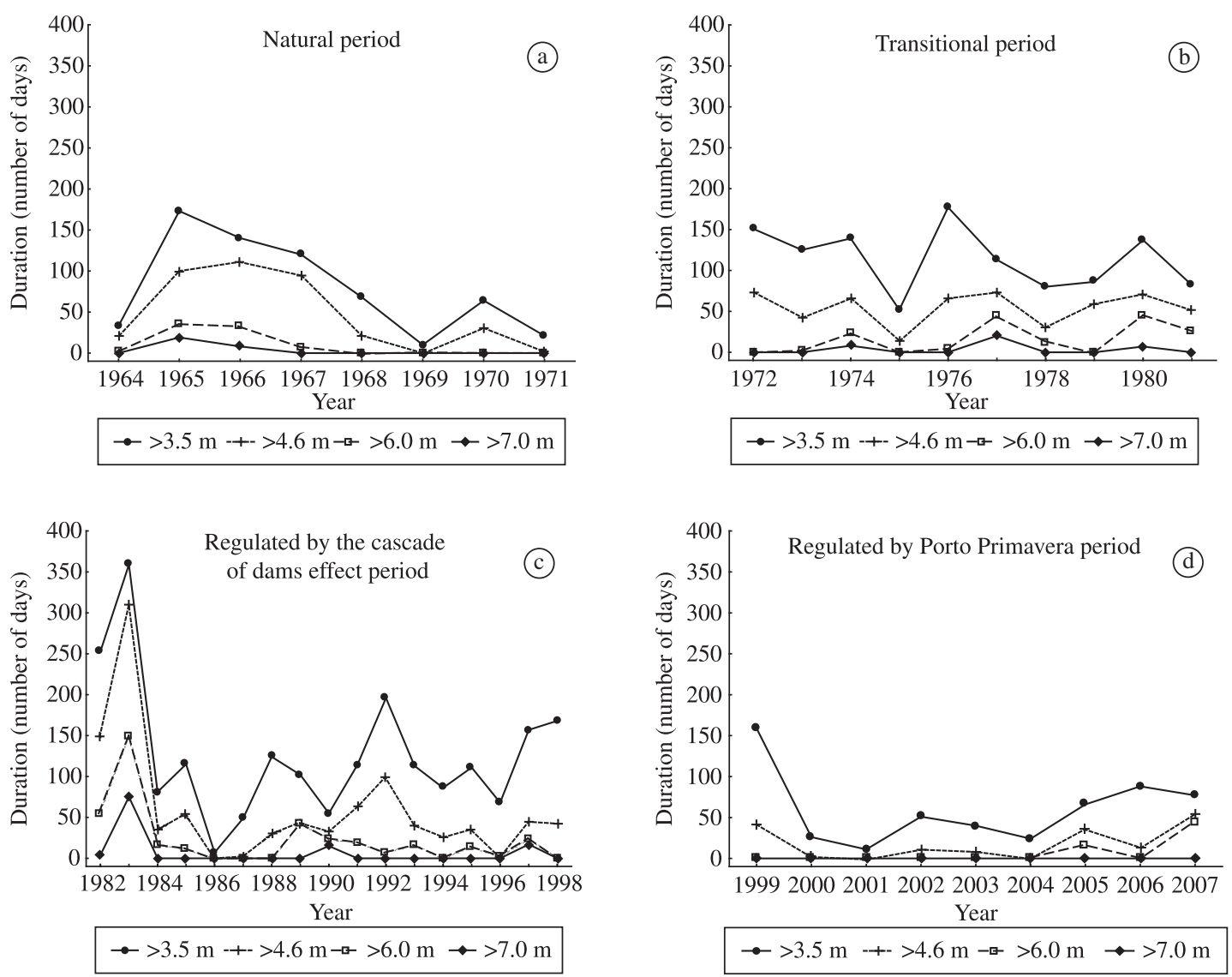

Figure 4. River level permanence in each river level interval during a) the natural period; b) the transitional period; c) the regulated by the cascade of dams effect period; and d) the regulated period (number of days). 

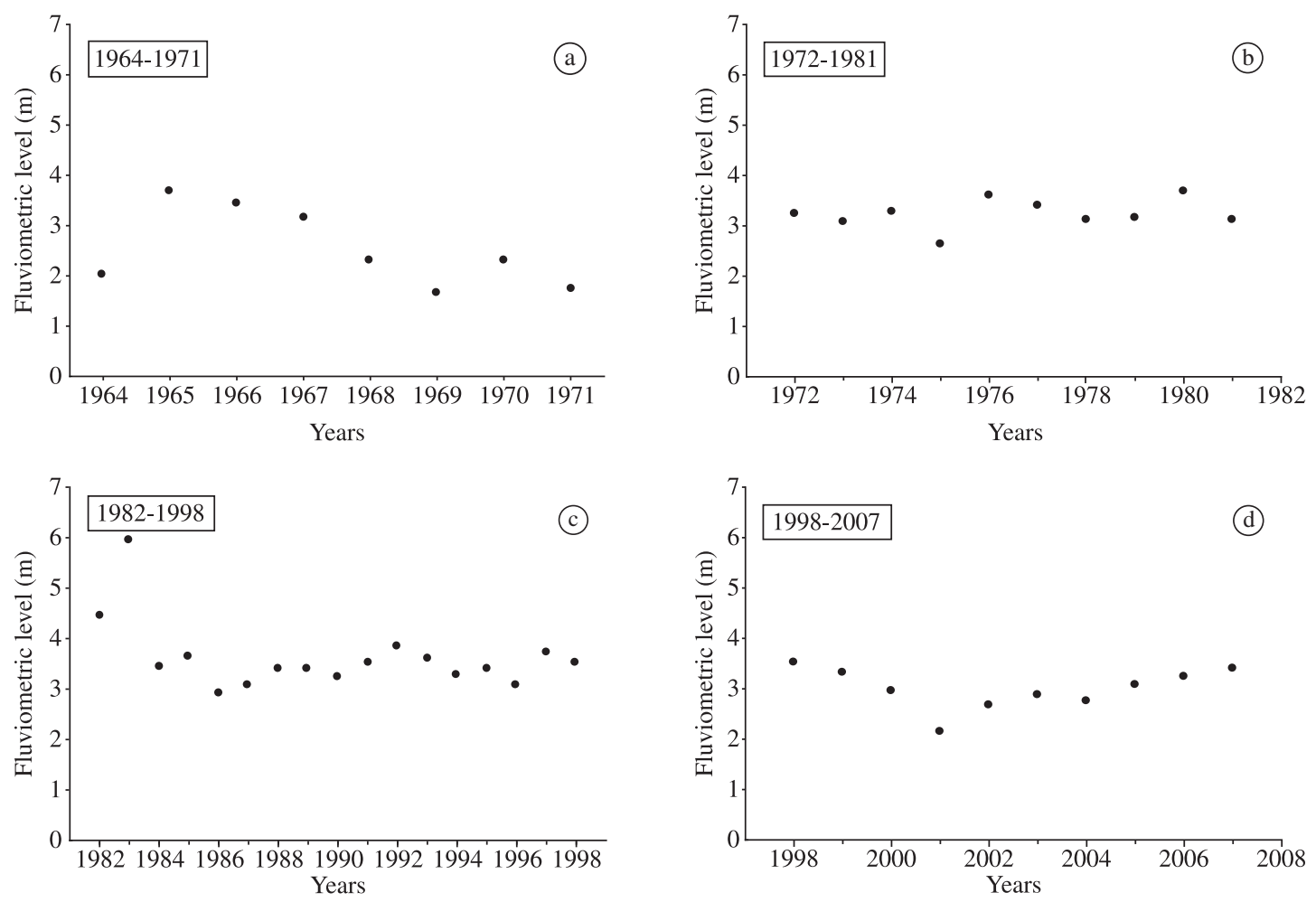

Figure 5. Annual average river levels at the Porto São José Station between a) 1964 and 1971; b) 1972 and 1981 ; c) 1982 and 1998; and d) 1999 and 2007.

1983 is noteworthy because of the large flood mentioned above. In 1986, there were no big flood events, in terms of magnitude or duration, although it had an annual average discharge close to $3.0 \mathrm{~m}$.

Finally, during the Regulated by the Porto Primavera Hydroelectric Power Plant Period, the average river level reading was $2.94 \mathrm{~m}\left(7,974 \mathrm{~m}^{3} / \mathrm{s}\right)$. In this period, annual average levels decreased until the year 2001 (Brazil energy crisis) and increased again until the year 2007. However, the annual average levels remained below $3.5 \mathrm{~m}$ (Figure $5 \mathrm{~d}$ ). The durations of the discharges are shown in Figure $4 d$. The values show the absence of significant flood events, since the water levels were below $7.0 \mathrm{~m}$ during this period. Only in 2005 and 2007 did the water level rise above $6.0 \mathrm{~m}$.

\subsection{Relationship between river level and outflow}

Figure 6 shows graphs based on the analysis of polynomial regression of the data from river levels and daily average discharges of each river interval. It is clear that the association between the variables was high, since each $\mathrm{R}^{2}$ is higher than 0.92 . However, the dispersion of the points in the first two periods shows that the use of the rating-curve was incorrect in several instances.

Differences between regression curves show that the fluvial section changed over time. Consequently, the relationship between the river level and the discharge also changed. Such modifications may be natural or manmade. Once known and expected, fluvial sections monitored for water level are periodically reevaluated in order to update their rating-curves. These reevaluations show that differences between regression curves show that the rating-curve changed throughout the recorded period, and that the river levels used in this work correspond to different values of discharge in the adopted time intervals.

The temporal variation of fluvial discharge values corresponding to each fluviometrical level is shown in Table 1. If the levels 3.5 and $4.6 \mathrm{~m}$ are considered, the values show that the discharge necessary to reach these levels diminished successively from the first period to the third period and increased in the fourth period. However, if the level $6.0 \mathrm{~m}$ is considered, the values show that the discharge value diminished from the first period to the second period, increased from the second period to the third period, and finally diminished in the fourth time interval. In turn, the $7.0 \mathrm{~m}$ discharge increased during the three first periods and was reduced after the year 1999 .

The data in Table 1 show that after the river damming (by the Porto Primavera Dam), the Porto São José section needed higher discharge rates to reach river levels close to or lower than $4.6 \mathrm{~m}$ and lower discharges to reach fluviometrical levels close to or lower than $6.0 \mathrm{~m}$. However, the dam interrupted the supply of detritic material to the river, and consequently, the Porto São José 

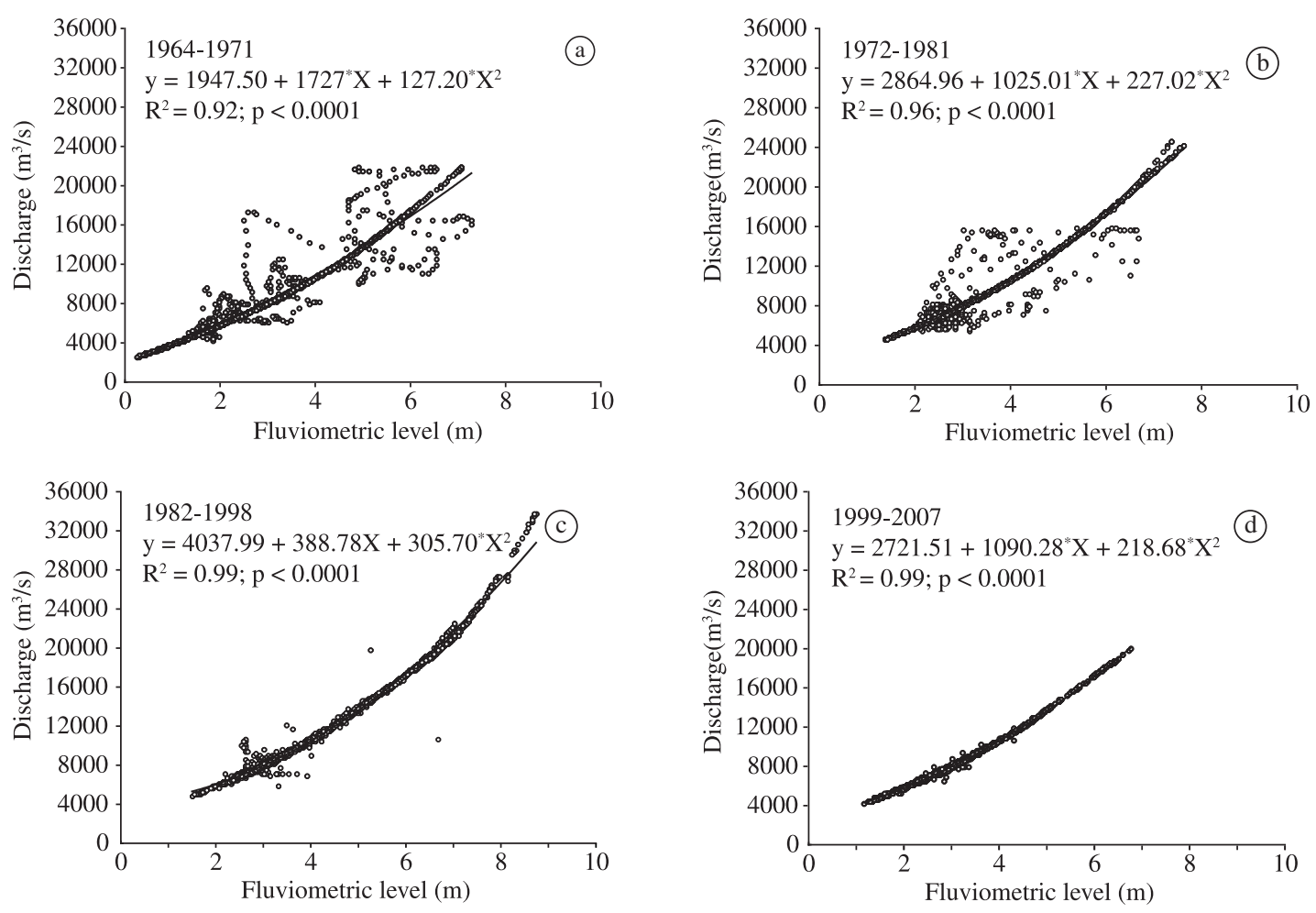

Figure 6. Resulting graphs of analysis of polynomial regression of Porto São José Station river level and daily average discharge data during a) the natural period; b) the transitional period; c) the regulated by the cascade of dams effect period; and d) the regulated period.

Table 1. Fluvial discharge values for each river level in different time periods.

\begin{tabular}{ccccc}
\hline Level $(\mathbf{m})$ & \multicolumn{4}{c}{ River discharge $\left(\mathbf{m}^{\mathbf{3}} / \mathbf{s}\right)$} \\
\cline { 2 - 5 } & From 1964 to 1971 & From 1972 to 1981 & From 1982 to 1998 & From 1999 to 2007 \\
\hline 3.5 & 9553 & 9233 & 9140 & 9217 \\
4.6 & 12587 & 12384 & 12295 & 12370 \\
6.0 & 17893 & 17188 & 17376 & 17140 \\
7.0 & 20274 & 21164 & 21739 & 21100 \\
\hline
\end{tabular}

section has been modified, according to Souza Filho et al. (2004).

As the fluvial section was modified, the relationship between the fluviometrical levels and the fluvial discharges may have been modified as well. Thus, the section rating-curve might not be valid anymore.

The regression analysis of river level and outflow data, for every year between 1999 and 2007, shows that the curves are statistically similar (Figure 7). This shows that the discharge values for the entire period were achieved considering the same rating-curve.

In order to check the rating-curve adjustment, the Porto São José Station river level data were compared with Porto Caiuá Station data. The same procedure was employed to evaluate the river discharge data. The value of the correlation between Porto São José and Porto Caiuá river level data was higher from 1990 to 1998 than from 1999 to 2006. The same occurred with the correlation between the fluvial discharges of both stations (Table 2). The reduction in the values of the Pearson correlations ( 0.96 to 0.92$)$ showed that the relation between both stations was modified, and that river level and discharge data confirm such a possibility because the values corresponding to the same river level differed in both time periods.

The variation of river level and river discharge at the Porto Caiuá Station related to the $3.5 \mathrm{~m}$ level in Porto São José (Table 2) was coherent with the Porto São José Station discharge increase. This did not occur for other reference levels. In this case, the Porto Caiuá data indicated that the Porto São José rating-curve values underestimated the discharge values of the river level readings equal to or greater than $4.6 \mathrm{~m}$. 


\section{Discussion}

The analyses based on river level data and fluvial discharge rates showed that the average level and the discharge increased period after period. Nevertheless, in the last time interval, the values were reduced but were still significantly above the values of the first period (Figure 8).

Rocha et al. (1998) had already observed the increase of values, but they worked with discharge data, and the values of average river level were not coincident. However, neither the period nor the annual average discharge change indicated that dams have influenced such values since the discharge variation could be natural, caused by increases in precipitation.
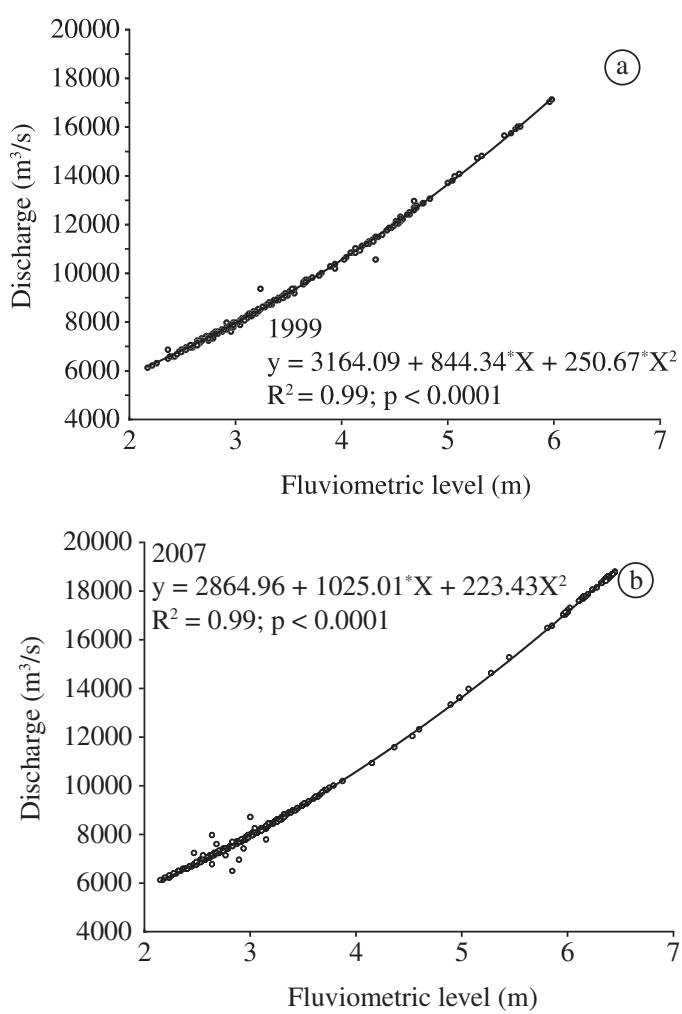

Figure 7. Resulting graphs of Porto São José Station daily river level and average discharge data analysis of polynomial regression in a) 1999; and b) 2007.

Table 2. Comparison between the river level values and the Porto São José and de Porto Caiuá Stations' discharges from 1990 to 1998 and from 1999 to 2007.

\begin{tabular}{|c|c|c|c|c|c|c|}
\hline \multicolumn{3}{|c|}{ Porto São José Station } & \multicolumn{4}{|c|}{ Porto Caiuá Station } \\
\hline \multirow[t]{2}{*}{$\begin{array}{c}\text { Level } \\
\text { (m) }\end{array}$} & \multicolumn{2}{|c|}{ Discharge } & \multicolumn{2}{|c|}{$\begin{array}{c}\text { Level } \\
(\mathbf{m})\end{array}$} & \multicolumn{2}{|c|}{$\begin{array}{c}\begin{array}{c}\text { Discharge } \\
\left(\mathbf{m}^{3} / \mathbf{s}\right)\end{array} \\
\end{array}$} \\
\hline & & & $90-98$ & $99-$ & & \\
\hline 5.1 & & & & & & \\
\hline 4.6 & & & & & & 140 \\
\hline 6. & 0 & 17 & 4.4 & 4.40 & 193 & 8691 \\
\hline .0 & 21700 & 21100 & 0.51 & 5.28 & 23417 & 22420 \\
\hline
\end{tabular}

Stronger evidence of the Porto Primavera Dam's influence is the duration (number of days) of the river levels above 3.5, 4.6, $6.0 \mathrm{~m}$ and $7.0 \mathrm{~m}$ (Figure 9 and Table 3). In this case, the duration of discharges when river level readings were above $3.5 \mathrm{~m}$ gradually increased. After the river damming (by the Porto Primavera Dam), the duration was reduced considerably. The data for the last period highlight both the reduced value of the duration in river level readings above $6.0 \mathrm{~m}$ and the absence of floods with river levels above $7.0 \mathrm{~m}$. Moreover, it must be noted that the average discharge of this period was

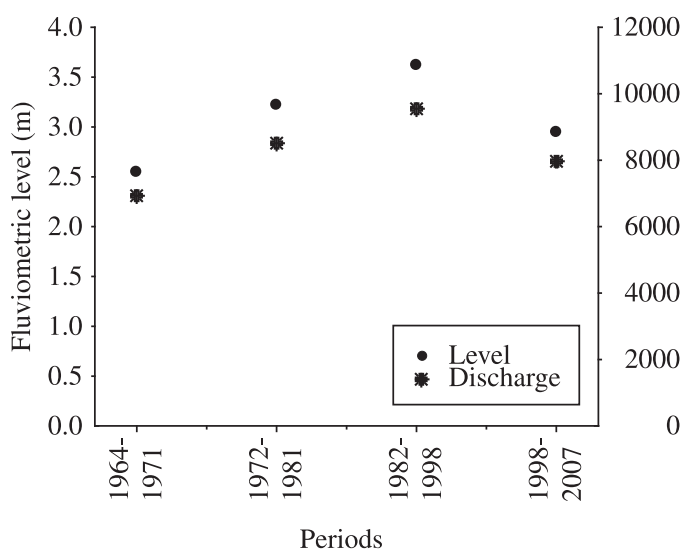

Figure 8. Temporal variation of the average river level readings of the four different periods.

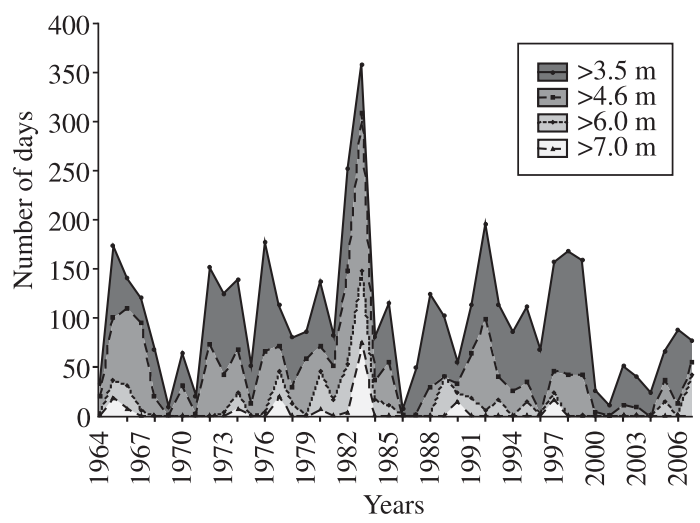

Figure 9. Permanence of different river levels at Porto São José Station.

Table 3. Annual average duration of discharges in different river levels in each period.

\begin{tabular}{ccccc}
\hline Years & $>\mathbf{3 . 5} \mathbf{~ m}$ & $\mathbf{> 4 . 6} \mathbf{~}$ & $\mathbf{> 6 . 0} \mathbf{~ m}$ & $\mathbf{> 7 . 0} \mathbf{~ m}$ \\
\hline $1964-1971$ & 79 & 47 & 10 & 3 \\
$1972-1981$ & 114 & 55 & 15 & 4 \\
$1982-1998$ & 127 & 59 & 22 & 7 \\
$1999-2007$ & 60 & 19 & 6 & 0 \\
\hline
\end{tabular}


Table 4. Fluvial discharge reading data at the Porto São José Station and the respective values inferred from the Porto Caiuá Station data.

\begin{tabular}{ccc}
\hline $\begin{array}{c}\text { Level } \\
(\mathbf{m})\end{array}$ & $\begin{array}{c}\text { Recorded } \\
\text { discharge }\left(\mathbf{m}^{3} / \mathbf{s}\right)\end{array}$ & $\begin{array}{c}\text { Calculated } \\
\text { discharge }\left(\mathbf{m}^{\mathbf{3}} / \mathbf{s}\right)\end{array}$ \\
\hline 3.5 & 9217 & 9320 \\
4.6 & 12370 & 12330 \\
6.0 & 17140 & 17215 \\
7.0 & 21100 & 21278 \\
\hline
\end{tabular}

higher than during the Natural Period, concerning both river level and outflow values (Figure 8).

The Porto Primavera Dam reduced the duration of every discharge above the $3.5 \mathrm{~m}$ river level (Figure 9, Table 1). This means that the influence of the channel on the plain has lessened and that the different degrees of connection between the fluvial channels and the lentic bodies have diminished.

This situation might have been aggravated by the channel alterations because they modify the relationship between the river level and the discharge in the upstream segment. Considering that the Porto Caiuá section has not been significantly modified, it is possible to simulate the probable discharge that could have happened in Porto São José. Table 4 shows both the values registered in Porto São José by means of the rating-curve and the values calculated using Porto Caiuá Station data.

A comparison between the values in Table 4 shows that the Porto São José Station rating-curve underestimated the discharge values of the fluvial section. Considering that these data coincide with the channel modification period, it is possible that later values were even more underestimated. Such data indicate that the channel modifications increased the efficiency of the drainage system. Consequently, a higher discharge is necessary to reach a certain level. These data suggest that the frequency in which water reaches higher levels and the discharge duration in higher levels were reduced, diminishing the connection between the river and the plain.

\section{Conclusion}

The analysis of the Porto São José Station data shows that, even though the existing upstream dams already controlled the Paraná River discharge, the Porto Primavera Dam operation reduced both the river discharge magnitude and that the highest discharge durations occurred after 1998.

The comparison between data from the Porto São José and Porto Caiuá Stations showed that Porto São José River section modifications changed the relationship between the river levels and the fluvial discharge. It also showed that a higher discharge rate is now necessary to reach a certain water level. Both situations affect the flood dynamics: they reduce the connection between the river and the plain, and they affect the low-level water inflow, but they mainly affect the homogenization conditions on high magnitude flood events.

If the efficiency of runoff keeps improving, and dam operators do not increase water release during flood periods, the connection between the floodplain and the Paraná River channel may disappear in the near future.

\section{References}

ANDRADE, IRA., 2008. O uso de técnicas de sensoriamento remoto na identificação de formas na região de Porto Rico, Planície de Inundação do alto rio Paraná, MS/PR. Maringá: Universidade Estadual de Maringá - UEM. 63p. Dissertação de Mestrado.

COMUNELlO, E., SOUZA FILHO, EE., ROCHA, PC. and NANNI, MR., 2003. Dinâmica de inundação de áreas sazonalmente alagáveis na planície aluvial do Alto Rio Paraná: estudo preliminar. In Anais do XI Congresso Brasileiro de Sensoriamento Remoto, Abril 05-10. Belo Horizonte: INPE. p. 2459-2466.

CORRADINI, FA., 2006. Processos de conectividade $e$ a vegetação ripária do alto rio Paraná - PR. Maringá: Universidade Estadual de Maringá - UEM. 70p. Dissertação de Mestrado.

CRISPIM, JQ., 2001. Alterações na hidrologia do canal a jusante da represa de Porto Primavera, Rio Paraná. Maringá: Universidade Estadual de Maringá - UEM. 25p. Dissertação de Mestrado.

HAYAKAWA, EH., 2007. Análise da variabilidade espacial e temporal dos sedimentos suspensos do Alto rio Paraná via imagens orbitais: região de porto São José - PR. Maringá: Universidade Estadual de Maringá - UEM. 81p. Dissertação de Mestrado.

IBARRA, JA., 2008. Aplicações fluviológicas na planície do alto rio Paraná (PR-MS). Maringá: Universidade Estadual de Maringá - UEM. 41p. Tese de Doutorado.

MARTINS, DP. and STEVAUX, JC., 2005. Formas de leito e transporte de carga de fundo do alto rio Paraná. Revista Brasileira de Geomorfologia, vol. 6, no. 2, p. 43-50.

MEURER, M., 2004. Regime de cheias e cartografia de áreas inundáveis no Alto Rio Paraná, na Região de Porto Rico - PR. Maringá: Universidade Estadual de Maringá - UEM. 54p. Dissertação de Mestrado.

ROCHA, PC., 2002. Dinâmica dos canais no sistema rioplanície fluvial do Alto Rio Paraná, nas proximidades de Porto Rico - PR. Maringá: Universidade Estadual de Maringá - UEM. 169p. Tese de Doutorado.

ROCHA, PC., SANTOS, ML. and SOUZA FILHO, EE., 2001. Alterações no regime hidrológico do alto rio Paraná como resposta ao controle de descargas efetuado por grandes barramentos a montante. In Anais do VIII Encuentro de Geógrafos de América Latina, Março 04-10. Santiago: Editora da Universidad del Chile. p. 28-39.

ROCHA, PC., SOUZA FILHO, EE. and FERNANDEZ, OVQ., 1998. Aspectos do controle de descargas efetuado por barramentos no alto rio Paraná. Boletim Paranaense de Geociências, vol. 46, no. 1, p. 117-122. 
SILVA, SA., 2007. Características do regime hidrológico do alto rio Paraná: modificações e aspectos ambientais. Maringá: Universidade Estadual de Maringá - UEM. 36p. Tese de Doutorado.

SOUZA FILHO, EE., 1994. Feições do sistema anastomosado pré-atual do rio Paraná. In Anais do XXXVIII Congresso Brasileiro de Geologia, Outubro 23-28. Camburiú: SBG. p. 407-409.

1999. Diagnóstico do meio físico e condições emergentes da planície do rio Paraná em Porto Rico (PR). Revista GEONOTAS, vol. 3, no. 3, p. 12.

SOUZA FILHO, EE. and STEVAUX, JC., 1997a. As barras fluviais da parte média do alto rio Paraná. In Resumos expandidos do VI Congresso da Associação Brasileira de Estudos do Quaternário - ABEQUA, Julho 27 - Agosto 03. Curitiba: ABEQUA. p. 265-269.

1997b. Geologia e geomorfologia do complexo rio Baia, Curutuba, Ivinheima. In VAZZOLER, AEAM., AGOSTINHO, AA. and HAHN, NS. (Eds.). A Planície de Inundação do Alto Rio Paraná. Maringá: EDUEM; NUPÉLIA. p. 03-46.
2004. Geology and geomorphology of the Baia-Curutuba-Ivinheima complex. In THOMAZ, SM., AGOSTINHO, AA. and HAHN, NS. (Eds.). The Upper Paraná River and its floodplain: physical aspects, ecology and conservation. Leiden: Backhuys Pubblishers. p. 1-30.

SOUZA FILHO, EE., ROCHA, PC., COMUNELLO, E. and STEVAUX, JC., 2004. Effects of the Porto Primavera Dam on physical environment of the downstream floodplain. In THOMAZ, SM., AGOSTINHO, AA. and HAHN, NS. (Eds.). The Upper Paraná River and its floodplain: physical aspects, ecology and conservation. Leiden: Backhuys Pubblishers. p. 55-74.

THOMAZ, SM., PAGIORO, TA., BINI, LM., ROBERTO, MC., ROCHA, RRA., 2004. Limnological characterization of the aquatic environments and the influence of hydrometric levels. In THOMAZ, SM., AGOSTINHO, AA. and HAHN, NS. (Eds.). The Upper Parana River and its floodplain: physical aspects, ecology and conservation. Leiden: Backhuys Pubblishers. p. $75-102$. 